\title{
Time to Play: The Difference Between Knowing and Showing
}

\author{
Matthew Etherington \\ Trinity Western University
}

\begin{abstract}
Children's play experiences demonstrate many benefits for learning, cognitive development, and self-awareness. Evidence reveals that children require regular amounts of play. Despite this evidence, play has been rapidly disappearing from the home, the neighbourhood, and the school over the last two decades. Curriculum reformers present empirical data to suggest that safety, health and fitness, and behaviour considerations compel a structured approach to playtime from Kindergarten through to Year 6 of primary school. In this article, I argue that one can know from personal experience that authentic play experiences are valuable and one can also show through personal experience that play is vital for learning. These two approaches defend play as a valuable learning experience for curriculum development.
\end{abstract}

Keywords: childhood; play; curriculum development; knowing; showing 


\section{Time to Play: The Difference Between Knowing and Showing}

The concept of play poses difficulties by definition (Gaskins, Haight, \& Lancy, 2007; SuttonSmith, 1997). The logic is, however, straightforward: Play involves personal inner control, "an intermediate area of experiencing” (Winnicott, 1971, p. 2), and an ability to invent reality (Leichtman, 1996). Play occurs when children are in relation to one another and established boundaries become fluid, dissolve, and soften. It involves free choice and is self-organized; often, it appears to the observer as chaotic and disorganized. Play embraces pretend play, body play, object play, outdoor play activities, rough and tumble play, and social play (Bergen \& Fromberg, 2009; Jarvis, 2007).

Play also entails, "activities wherein children can imitate, fantasize and practice makebelieve safely by testing roles and feelings" (Van Manen \& Levering, 1996, p. 91). The core of play is at all times unscheduled, independent, and reflective, permitting children to decompress (American Academy of Paediatrics, 2007). It can involve watching others play, playing alone or in the middle of a group, sharing materials, talking, or organizing roles with specific goals. Play does not include passive entertainment such as television or computer games; rather, authentic play involves children who are independent and actively engaged with their imaginations. In the end, the best definition might be that "people are playing when they say and believe they are playing” (Cook, 2000, p. 101).

Play is so important to a child's optimal development that the United Nations High Commission for Human Rights has recognized it as a right of every child (Ginsburg, 2007). Today - while research continues to confirm that play is critical for the emotional, social, and physical development of children (Piaget, 1970; Vygotsky, 1978; Berk, 2001; Bergen, 2002)— play appears to be in danger. Schoolchildren from Kindergarten to Grade 6 are experiencing a reduction in the space and time available for play (Bergen \& Fromberg, 2009). When play does occur, it is often delivered in the "quasi-militaristic approaches" of student movement, authority, obedience and submission, dressage, and drill (Symes \& Preston, 1997, p. 216). Government initiatives to encourage academic development, proposals to reduce childhood obesity (Rodgers, 2009), plans to reduce in-school bullying (Matthews, 2008), measures to increase emphasis on accountability and safety, and response to fears of anarchy (Yang, 2000) are all contributing factors to transforming genuine play from an unhurried creative experience into professionalized and competitive work (Elkind, 2001).

With this understanding and context in mind, I advance a normative argument for the importance of childhood play-in home, school, and childcare settings. I argue that unstructured play encourages the development of personal and social skills (e.g., autonomy, initiative, independent decision-making, self-awareness, empathy, social mobility) and academic skills and knowledge acquisition (e.g., cognitive and linguistic competence, abstract thinking, and mathematical ability). I argue that opportunities for both unstructured play and teacher-directed learning are essential to the development of the whole child.

To advance this argument, I distinguish between ontology (the order of being) and epistemology (the order of showing). I draw a novel distinction between knowing and showing the benefits of play, arguing that (a) we can know from personal experience that authentic play 
experiences are veridical (valid and truthful) and (b) we can show that play is vital for learning. These two approaches defend play as a valuable learning experience to be considered when reforming curriculum.

I begin by defining the proper ground of knowing play to be purposeful as the inner work of personal experience-what reformed epistemologists have termed a properly basic belief (Hoitenga, 1991). ${ }^{1}$ To illustrate knowing the benefits of play, I reflect upon my own experiences as both child and educator. I characterize personal experience as self-authenticating, meaning that personal experience is veridical and unmistakable for the one who has it. Such an experience provides one with both a subjective assurance and objective knowledge of that truth.

I, then, define showing the value of unstructured play through a scientific approach. This approach comprises repeated trials, careful observation, testing and re-testing, hypothesizing, and finally, drawing a result from the many repeated trials. I argue that concrete evidence may properly confirm the assurance provided by personal experience. In illustration, I cite a body of academic literature that provides compelling evidence of the many benefits of play. Finally, I discuss the challenges of managing the "play-deprived," and I recommend that play be given a magisterial (dominant) role within the Kindergarten to Grade 6 school curriculum.

\section{Knowing Play to be Valuable}

In the classroom, teachers face the challenge of choosing and organizing learning activities that balance the development of knowledge, skills, and experiences. What one determines to be an important learning experience, however, may in fact have minimal supporting research, and thus, may be difficult to prove as valuable.

In the case of play, there is much research promoting the benefits of structured teacherled activities. Mahoney, Harris, and Eccles (2008), for example, have argued that structured activities and teacher-directed activities build relationships (with peers and adults), skills, selfesteem, and sense of purpose. Child psychologists Hirsh-Pasek and Golinkoff, with Eyer (2003) have similarly argued that a child's skill-building and intellectual awakening occur during purposeful and structured teacher-led activities. How then can a teacher defend the value of play in the classroom? Confronted with empirical data that claims play has little or no value for learning, he or she faces an epistemic deadlock.

The philosophical approach I defend in this article is that both knowing and showing are justified epistemic positions for discerning the truth. I argue that reason-in the form of rational arguments and evidence-plays an essential contingent and secondary role in showing structured play to be a valuable learning experience for children. It is secondary to the role of our personally knowing play to be a plausible and valuable learning experience. The proper ground of knowing play to be purposeful is the inner work of personal experience, otherwise known as a properly basic belief (Hoitenga, 1991).

While the scientific methodological approach has its merits, prioritizing personal knowing as a properly basic belief with no need for empirical verification serves to confirm (a) the affective dimensions of knowledge and (b) the authenticity of our beliefs vis-à-vis the human 
experience. An illustrative example is my belief and assurance in the existence of the past, which is properly basic because it does not depend on other beliefs or evidence for confirmation. Similarly, my belief that play is a significant part of holistic learning is properly basic because it does not depend on other beliefs or evidence. A properly basic belief provides validity for the justification of play because it is part of the human experience; one can simply know that play is a valuable learning practice.

In considering the position of a child, it seems to me that the fundamental way in which a child knows the worth of play is by his or her own experiences. That is, a child has the epistemic right to hold onto the value of play as a properly basic belief. It is a properly basic belief because it is veridical to one's personal knowledge. A lack of concrete evidence for a properly basic belief does not negate its truth. In popular texts on learning, writers have referred to this personal understanding as "lived experience" (Van Manen, 1997; Merleau-Ponty, 1968), giving it ontological expression. Lived experience is self-authenticating; however, it may not always be veridical, concrete, or even compelling. For example, a child goes on an imaginary bike ride with a friend and experiences a certain togetherness and closeness of feeling, maintaining a participation in the outside and a private preserve on the inside. This unique play awareness is called “play consciousness” (Van Manen, 1997, p. 37).

Why is the experience of the imaginary bike ride so important? Because, as Sokolowski (2000), notes, in the philosophy of the past three or four hundred years, human experience has come to be understood in the cramped confinement of psychology (p. 9). If we lack the concrete evidence to support our experience, for example, the imaginary bike ride, then the experience is not of anything at all. In contrast, although the child may not have the skills or ability to show others that the imaginary bike ride was not an illusion but a real lived experience, the child knows that it was adequately real because it was not only private, but also it was a significant experience that she can describe publicly in detail with others.

Of particular interest to educationalists is Carl Rogers' (1951) model of the freedom to learn. The freedom to learn, as Rogers argues, is the freedom to achieve self-actualization, which is the right and privilege of every child. However, belief in the freedom to learn rests upon other more rudimentary beliefs, for example, that play equates to freedom or that play leads to selfactualization. Although the child may be confined in the space available for play, the main point is that the experience of unstructured free play gives the child a depth of themselves as "I" in that they are able to transcend their environment. The child goes from the empirical self (the confines of the concrete environment) to the transcendental self (the child transcends the immediate environment), (see also Sokolowski, 2000, pp. 112-129).

So, what if a teacher's belief in the priority of the freedom to play by choice conflicts with a belief supported by evidence to the contrary? In most cases, the circumstances that ground a belief confer only a prima facie justification, not an ultima facie justification to that belief. Yet, a little reflection will show that such an epistemology is as educationally inadequate as a listenand-learn pedagogy.

Consider, for example, a student raised in a play-enriched home who organizes a selfinvented game of hide-and-seek under the observation of a teacher. As he begins the game, he 
finds his attempts constantly rebuked. He casts about for answers but has no vocabulary to answer the objections. He feels defenceless before his teacher's criticisms, having nothing but the reality of his own experience and imagination to oppose the arguments. It seems irrational for such a student to continue his belief in the value of his game because he has an epistemic obligation to give up the invented game and fall in line with the teacher, who knows better. Surely, this is unconscionable. How can one be obligated to ignore the self-authenticating truth of personal experience? Granted, the teacher may find that the "cat" is only a toy, or that "man" was only a shadow; such occasional mistakes, however, do not cause us to become suspicious about everything we experience (Sokolowski, 2000). Are we going to deny children the joy, privilege, and right to exercise and experience their freedom of choice for unstructured play? To answer affirmatively seems unthinkable. So long as we require extrinsic defeaters for the defeaters brought against free play, the sting of evidentialism has not been removed (Cowan et al., 2000).

It is important to insist on the self-authenticating nature of personal experience. The claim that personal experience is self-authenticating is an intrinsic defeater of the defeaters brought against it. That is to say, it is something believed to be true that has such a high degree of warrant that it simply overwhelms any putative defeater. Even when a child is confronted with what are for him unanswerable objections to the value of play, he is, because of his experience, within his epistemic rights (nay, under epistemic obligation) to believe that what he has experienced is valuable.

\section{The Importance of Separating Knowing and Showing}

What role remains for rational argument and evidence? When knowing the value of play, it is clear that evidence will play a minor role. Here I find the distinction between knowing and showing to be quite helpful. In showing, evidence is more authoritative in comparison with personal experience, and acts as the ultimate decider and judges its truth or falsity. We must weigh the evidence and arguments both for and against the truth of personal experience in order to adjudicate the issue without any reliance on the truth of experience.

In its subservient role, however, reason yields to and serves personal experience. It is a useful tool in helping us to understand and defend what we know to be important and of value. Dilthey (1985), Merleau-Ponty (1968), Gadamer (1975), and Ricoeur (1981) all endorsed the veridical concreteness as well as the ontological reality of lived experience, as did Max Van Manen (1997).

The child's experience and enthusiasm for engaging in play that is unstructured and undirected implies that Dilthey, Merleau-Ponty, Gadamer, and Ricoeur were correct. Rational argument and evidence can confirm in the parent's and/or teacher's mind the truth witnessed to the parent or teacher. What they know via their own personal experiences with play, they may also know via argument and evidence. If, due to the contingencies of one's life situation, confirmation by argument and evidence is unavailable, the basis of one's experience remains secure. 
By contrast, those who subscribe to an evidence-based showing use of reason face severe difficulty: They deny benefits of play to all those who lack the ability, time, or opportunity to understand and assess the scientific arguments, research, and evidence. They legitimize an intellectual elite - a "priesthood" of educational psychologists and behavioural scientists—who dictate whether or not play has validity to the masses of teachers, parents, and children.

Insofar as scientific arguments and scientific evidence for play are available, anyone ought to regard these not as supplying the basis for his belief but as a welcome and provisional confirmation of a properly basic and warranted belief in the value and benefit of play for children. As Plantinga, (as cited in Hoitenga, 1991) has suggested, external proofs are always welcome, but are not necessary for the verification of one's belief. No external proofs are needed if one holds a properly basic belief that play experiences are veridical.

\section{Reflections on the Role of the Researcher}

In keeping with an inquiry of experience, I offer my own experience (as child and later as a teacher) to illustrate this knowing of the value of play that I have defined. Raised in a playenriched loving home, I became an advocate of play in my $3^{\text {rd }}$ year of high school. Play-enriched students who shared their experiences with me seemed to be living on a similar plane of reality to mine. Their commitment to the benefits of play imparted meaning and a joyous peace to their lives and my own. Knowing the value of play — and full of enthusiasm and commitment — I went off to university to study primary teacher education in the 1990 s.

The 1990s were characterized by a drive to universalize education, in which quality often took a back seat. At the World Education Forum in Dakar, Senegal, the eighth recommended action for basic education was:

To create safe, healthy, inclusive, and equitably resourced educational environments conducive to excellence in learning with clearly defined levels of achievement for all. To improve all aspects of the quality of education and ensure excellence of all so that recognised and measurable learning outcomes are achieved by all. (EFA Global Monitoring Report, 2002)

One corollary of idealism in the educative process is that students require discipline and self-mastery and the curriculum is rational, purposeful, and strongly intellectual. ${ }^{2}$ Under the guise of idealism, schools of education have focused on intellectual rather than on practical or concrete experiences. Hands-on experiences were de-emphasised. The focus was on imparting mental skills and the teacher was the model. If learning did not have purpose or value for measurable success, it was not valuable to everyday life. Structured play activities directed by teachers aimed to be more inclusive of all children and geared towards developing the intellectual person. To create a safe, healthy, inclusive, and equitable learning environment, schools began monitoring play.

Educators who defended play were regarded with scepticism and cynicism. I was dismayed to see teachers whose intellectual abilities I admired lose their enthusiasm and renounce their commitment to play in the name of the "education for all movement." In my 
education classes, I learned that none of the reasons given for play were sound. Students touted educational idealism as a virtue of the mature teacher's life. One was supposed to follow the demands of idealists wherever they might lead.

This frightened and troubled me. Play had invested my life with such significance that I knew it to be valuable. I confided to one of my colleagues one day, "I guess I'm never going to be a real teacher. Even if all the data showed play to be insignificant for learning, I would still defend its significance for children's learning at school. ... My lived experiences are too real.”

I went through a temporary flirtation with Skinner's behaviourism, although my mind could not rest long in the position that freedom is an illusion. As often happens in the lives of earnest students, the reading of certain books proved pivotal in my thinking and directed my life along a different route. The first were Martin Buber's (1958) acclaimed classic I and Thou and Nel Noddings' (1992) The Challenge to Care in Schools, which persuaded me that an ethic of care might be used to show the systematic inconsistency of schooling and its relation to education. The second was William Glasser's (1998) book Choice Theory, which stunned me with its demonstration that there were, after all, persuasive, cogent arguments to show that school (not education) interferes with a love of learning. I learned that it is possible to present a sound, convincing, positive case for the benefits of play as a genetic human need.

Still I could not embrace the view that rational arguments constituted the essential foundation for my beliefs and commitment to encourage play. I put the issue on the back burner while I solidified my career as a teacher, working with Kindergarten children all the way through to Grade 6. The issue came to the fore again in 2004, during a challenging classroom experience. It was while considering the problem of unstructured learning experiences that $I$ hit on the distinction between knowing and showing the value of play as a significant learning experience. It is tremendously liberating to know that the reality of our experience is recognized as knowledge and to commend it without being dependent upon the vagaries of scientific confirmation. It was gratifying to me when David Elkind (2001) confirmed this in The Hurried Child, showing that children are required to mimic adult practicality and efficiency while secretly yearning for time to know thyself, by themselves, freely.

\section{Showing Play to be Valuable}

In this section, I am concerned with the challenge of proving to another person that play is valuable for learning. Even if I know personally — on the basis of experience-that play benefits learning, how can I demonstrate to somebody else that this is authentic and true?

Showing structured play to be a valuable experience for learning requires a scientific approach. This approach comprises repeated trials, careful observation, testing and re-testing, hypothesizing, and, finally, drawing a conclusion from the many repeated trials. Among its practitioners are such great figures as B. F Skinner, with his famous stimulus-response theory of learning, and Ivan Pavlov, the Russian physiologist. Under the conditions of science, entities that lack physical, observable, and repeatable dimensions are irrelevant (Peterson, 1986). The scientific approach and its practitioners are so impressive that they have remained compulsory reading for teacher education applicants until today. In the act of showing, evidence must assume 
a primary and appropriate role; the work of personal experience plays no part in the demonstration proper but consists in opening the heart of the resistor to persuasion.

In the Kindergarten to Grade 6 classroom, the social learning theory of Vygotsky (1978) has children carefully instructed and guided by those more knowledgeable-with the confidence that this increases the potential for learning (Yang, 2000). We treat children as active learners who construct their own knowledge and understandings about their world (Hohmann, Weikart, \& Epstein, 1995). In the classroom, this methodology, juxtaposed with established educational theory, is reasonable and in most cases effective. For example, teachers show children how to play games, how to take turns, and how to organize themselves. They learn the rules of engagement and communication, the rules of sportsmanship, and the importance of participation. In the classroom, children's work and play is naturally structured.

Nonetheless, as Elkind (2007) has observed, teacher-led and adult-driven activities often presuppose that structured activities increase learning. However, such "premature structuring" can lead to the creation of "undeveloped personalities" (Elkind, 2007, p. 199). There is evidence to show that too many teacher-led activities can produce stressed children who display a lack of social competence with their peers. There is also extensive evidence to show that play, on the other hand, develops autonomy, initiative, independence, problem-solving skills, comprehension ability, and communicative repertoires (Lewis, Boucher, Lupton, \& Watson, 2000; Fromberg \& Gullo, 1992).

Throughout history, many prominent educationalists and health care professionals have recognized the importance of play and argued that education has an ethical duty to liberate children's creativity and autonomy. The Brazilian philosopher and educationalist Paulo Freire (1970) stressed the potential of education to liberate people who would otherwise remain oppressed by their circumstances. In the words of Freire (1970), the over-scheduled child is the object-“lifeless and petrified.”

In Achieving Emotional Literacy, Steiner (1997) argued that children schooled in a highly structured environment eventually accept, as natural, their role as sub-servants. This environment produces what Steiner calls "the controlling child"-a child who has learned to control and dominate others, as he or she has been controlled. Van Manen (1997) noted that without play, children could not experiment with their own selves, their roles, strengths and weaknesses, good and bad habits, and ideas. Play, by comparison, is shown to develop empathy, creativity, and autonomy.

In play, young children can take on the roles and perspectives of other people. Play is "the theatre of the young” (Paley, 2005). It offers a make-believe world in which children can be themselves (Jacobson, 2008), engage in trial and error, and form their imaginative instincts (Scott \& Panksepp, 2003). According to Hirsh-Pasek and Golinkoff with Eyer (2003), the opportunities afforded by play are critical for determining self-awareness, understandings of boundaries, and later social mobility. As Pomerantz and Bell (2007) have observed, "linguistic competence develops through the experience of play - the more and more varied experiences a learner has, the more that person will develop a strong and broad communicative repertoire” (p. 20). In the 1980’s, Pepler and Ross (1981) also established that play improves creativity, which 
ultimately helps children to solve problems (Wyver \& Spence, 1999). Creativity and independent thinking are 21st century skills that children need for future employment (Hirsh-Pasek, Golinkoff, \& Eyer, 2003).

In the early 1990s, Pellegrini and Smith (1993) proposed regular inclusion of play in education for the emotional development of children. Their message was that play advances social development, decreases stress, and reduces misbehaviour at school. Scientific trials have also shown that children tend to be more creative and self-confident and have fewer behavioural problems if parents play with them regularly at home. Clinical trials by Francine Ferland (2002), a professor in the Occupational Therapy Program at the University of Montreal and a leading researcher on play and its impact on a child's development, suggests that for the emotional wellbeing of children, parents should let their children direct their playtime and should not be concerned with rules or teaching. Playtime, suggests Ferland, should be as relaxed, enjoyable, and rule-free as possible.

By maximizing freedom of thought and creativity, children ultimately satisfy their physiology. ${ }^{3}$ Clinical trials by Scott and Panksepp (2003) have established that play releases brain-deprived neurotrophic proteins, which stimulates development of new neurons in the brain, which in turn stimulates social learning and appropriate reactions to new learning situations. Ginsburg (1989) discovered that young children engaged in higher mathematical cognitive skills, such as counting and sorting, during unstructured lessons with minimal teacher direction.

Bergen (2002) has associated cognitive competence, linguistic competence, and abstract thought with pretend play. This information was of particular interest in the 1960s when Smilansky (1968) demonstrated the value of socio-dramatic play for academic learning. Three decades later, Smilansky (1990) found that Israeli and American children's ability to play was directly linked to skills such as better verbalization, higher language comprehension, more curiosity, better perspective, and all skills necessary for academic success. We know that problem solving in most school subjects requires a great deal of make-believe, visualizing how people once lived, reading stories, imagining a story, and writing it down.

The German educationist Friedrich Fröbel (1826), American philosopher John Dewey (1902), psychiatrist William Glasser (1998), and more recently, educationalist John Gatto (2005) have all reinforced the same message: Education must teach people how to be independent problem solvers. Education should offer freedom of choice, self-responsibility, autonomy, creativity, and recognition of individuality. Evidence shows that play is central to achieving these goals.

\section{Discussion: Symptoms of the Play-Deprived}

In recent years, parents, teachers, and the public have raised student misbehaviour as an area in need of improvement (Brown \& Becket, 2006). In response, many Kindergarten to Grade 6 schools have emphasized discipline and control in an attempt to reduce unacceptable student behaviour (George, 2009). This has led schools to adopt two different forms of management: reactionary and preventative. A reactionary response invokes an immediate rejoinder to misbehaviour. The preventative approach involves creating safe places to learn or classroom 
environments that encourage self-directed learning leading to appropriate behaviour (Little \& Akin-Little, 2008).

Although creating safe places to learn has gained wide approval from Kindergarten to Grade 6 schools, many teachers still respond to misbehaviour using a default reactionary pedagogy that consists of restricting play opportunities and exercise this as a form of punishment and control (Zentall \& Javorsky, 2007).

In the light of the personal testimony and evidence presented to defend the value of play, this paper argues that teachers should in fact be doing the opposite. If they want well-behaved pupils, teachers should be maximizing opportunities for unstructured play. Creating safe places where children are free to play helps children learn how to be sociable, promotes healthy child development, and even maintains strong adult-child bonds (American Academy of Pediatrics, 2007). Creating safe places where children are free to play ultimately contributes to their emotional well-being and improves their social awareness and maturity.

A decline in play has in fact contributed to a steady increase in children labelled with attention deficit disorders. Murray (2008) notes the clinical trials of behavioural psychologist Alan Fridlund, who established that restrictions on play are partially responsible for a steep increase in attention deficit disorders. He argues that there is a direct relationship between the incidence of attention deficit disorders and the physical restrictions placed upon students. In practice, there is increasing emphasis on children being able to sit still in classrooms for long periods of time (Wells, 2003). As a result, there is little if any unstructured time left in the classroom.

Pelligrini (2005) agrees that there is a danger of losing play as schools replace playtime with more academic classes and that there is an associated rise in attention deficit disorders. Play facilitates socializing; restricting play leads to inadequate social skills—one of the prime warning signs of attention deficit disorders (Murray, 2008). While there is some research showing that play could increase the hyperactive behaviour of children (Antrop, Roeyers, \& De Baecke, 2005), it may simply be that such children do not have enough playtime to "blow off steam." They may have trouble settling down in the transition period from playtime to the quiet time of the classroom. The method of instruction that is given to children returning from playtime may also be unclear, imprecise, or inconsistent.

Clinical trials by Burns, Andrews, and Szabo (2002) have also found that highly structured environments with minimal or no play opportunities increase the number of young people who describe themselves as depressed. Using the term "learner helplessness," these researchers concluded that students compelled against their will to participate in structured teacher-directed games, performed unsuccessfully eventually caused learners to conclude that they were useless as members of a group. Before long, such students are ostracized by their peers, bullied, and eventually learn to depress (Glasser, 1998).

Wenner (2009) has taken this one step further, arguing that early career burnout in the workplace, as well as misbehaviour in schools, correlates with a reduction in play. According to 
Wenner, play offers a release from the pressures of structured work commitments. Play deprivation can lead people of all ages to de-motivation and emotional dissatisfaction.

From the moment children arrive at school, they are directed, managed, facilitated, evaluated, accessed, observed, classified, reinforced, and continually supervised (Gatto, 2005). This paper argues that research shows clear links between this overblown surveillance of schoolchildren and the development of attention deficit disorders, depression, and later career burnout in adulthood. It is clear that children need to be socially competent and that teachers need to create more space for them to do "nothing” (Hirsh-Pasek, Golinkoff, with Eyer, 2003, p. 203). Play provides a necessary break from the tightly structured environment of school.

\section{Conclusions and Recommendations}

In a materialistic and product-driven world, play is viewed as the antithesis to progress-if it does not produce something tangible, it has little value (Wenner, 2009). Contemporary schooling demands an "effective" use of children's unstructured time. There was a time when children could sit, chat, and "muck" around. For the youngest child, play "provided the opportunity for a delicious reversal of the laws of nature” (Factor, 2004, p. 146).

Although adult supervision increased in the 1950s and playground equipment was almost non-existent, children showed their flexibility, invention, and experimentation through a plethora of singing games, chasing games, counting and hiding games, and imaginative games. Children did not require structured and teacher-directed formal play. This squares well with the insights of past and contemporary thinkers who defended the claim that a child's greatest achievements were possible in play. There has always been a link with the co-dependency of cognitive development, imagination, and ample play.

Throughout this paper, I have defended the productive value of play, employing a distinction between ontology (the order of being) and epistemology (the order of showing). I have argued that we can (a) know from personal experience that authentic play experiences are veridical and (b) show that play is vital for learning. The scientific methodological approach has its own merits for substantiating what is important for curriculum inclusion. However, prioritizing play within the understanding of a properly basic belief (which has no need of empirical verification) fully recognizes the affective dimensions of learning and supports the authenticity of the human experience. The affective dimensions of learning recognize the whole child in his or her cognitive/intellectual, physical, social, emotional, and personal complexity.

Therefore, a more holistic understanding of the benefits of free play could involve a commitment to a child's own personal experience by making a fundamental distinction between the worth of knowing and showing. Knowing that play is vital for the holistic development of young children involves an ontological awareness which is a reality available to us all. To understand the importance of play, parents and educators should also recall the salience of their own play during this age period.

In contrast, showing play to be an important part of a child's emotional and social development requires a different methodology—one of clinical trials and empirical verification. 
In this article, I show that play is important to the holistic learning of children. I present research showing play to encourage the development of personal and social skills (e.g., autonomy, initiative, independent decision-making, self-awareness, empathy, social mobility) and academic skills and knowledge acquisition (e.g., cognitive and linguistic competence, abstract thinking, and mathematical ability). I also reveal links between play-deprivation and a rise in depression and attention deficit disorders in schools.

Although educators have adequate grounds to show that play is important for inclusion in the school curriculum, it appears that research has yet to alter curriculum standards and outcomes. The push to minimize play continues. While imagination, creativity, and play do not reflect well in the contemporary school playground, the outcome with a reduction in the spaces available for play is obvious. The contemporary school playground is safe and highly predictable (Gleave \& Cole-Hamilton, 2012), but modern playgrounds present little chance for experimentation or error, thus robbing children of an opportunity to learn by making mistakes.

If included in the contemporary curriculum, regular amounts of play within available spaces could liberate a child's imagination and social skills in all the key learning areas, not to mention helping to maintain and control aggression. I conclude with the recommendation that a balanced, unified curriculum approach should include abundant whole class, small group, and individual play experiences. 


\section{References}

American Academy of Paediatrics. (2007). The importance of play in promoting healthy child development and maintaining strong healthy parent-child bonds. Retrieved from http://www.aap.org/pressroom/playFINAL.pdf

Antrop, I., Roeyers, H., De Baecke, L. (2005). Effects of time of day on classroom behaviour in children with ADHD. School Psychology International, 26, 29-43.

Bergen, D. (2002). The role of pretend play in children's cognitive development. Early Childhood Research and Practice, 4(1), 1-13.

Bergen, D., \& Fromberg, D. P. (2009). Play and social interaction in middle childhood. Phi Delta Kappan, 90(6), 426-430.

Berk, L. E. (2001). Awakening children's minds: How parents and teachers can make a difference. New York: Oxford University Press.

Brown, L. H., \& Becket, K. S. (2006). The role of the school district in student discipline: Building consensus in Cincinnati. Urban Review, 38, 235-256.

Buber, M. (1958). I and thou. R. G. Smith, (Trans). New York: Charles Scribner’s Sons.

Burns, J. M., Andrews, G., \& Szabo, M. (2002). Depression in young people: What causes it and can we prevent it? Retrieved from http://www.mja.com.au/public/issues/177_07_071002/bur10371_fm.html

Cook, G. (2000). Language play, language learning. Oxford: Oxford University Press.

Cowan, S. B., Craig, W. L., Gundry, S. N., Feinberg, P. D., Clark, K. J., \& Frame, J. M. (2000). Five views on apologetics. Michigan: Zondervan.

Dewey, J. (1902). The child and the curriculum. Chicago: University of Chicago Press.

Dilthey, W. (1985). Poetry and experience. Princeton, NJ: Princeton University Press.

EFA Global Monitoring Report. (2002). Is the world on track? Retrieved from http://www.unesco.org/education/efa/monitoring/monitoring_2002.shtml

Elkind, D. (2001). The hurried child. Massachusetts: De Capo Press.

Elkind, D. (2007). The power of play: How spontaneous, imaginative activities lead to happier and healthier children. Massachusetts: Perseus Book Group.

Factor, J. (2004). Tree stumps, manhole covers and rubbish tins: The invisible play- lines of a primary school playground. Childhood: A Global Journal of Child Research, 1(2), 142-154. 
Ferland, F . (2002, September). The importance of play for children. Occupational Therapy Now. The Canadian Association of Occupational Therapists. Retrieved from http://www.caot.ca/default.asp?ChangeID=65\&pageID=507

Freire, P. (1970). Pedagogy of the oppressed. New York: Continuum Publishing Company. Fröbel, F. (1826). On the education of man. Keilhau/Leipzig: Wienbrach.

Fromberg, D. P., \& Gullo, D. F. (1992). Perspectives on children. In L. R. Williams \& D. P. Fromberg (Eds.). Encyclopedia of early childhood education, (pp. 191-194). New York: Garland Publishing, Inc.

Gadamer, H. G. (1975). Truth and method. London: Sheed and Ward.

Gaskins, S, Haight, W., \& Lancy, D.F. (2007). The cultural construction of play. In G. Artin \& S. Gaskins, (Eds.) Play and development: Evolutionary, sociocultural, and functional perspectives (pp. 179-202). Mahwah, NJ: Erlbaum.

Gatto, J. (2005). Dumbing us down: The hidden curriculum of compulsory schooling. Gabriola Island, BC: New Society Publishers.

George, S. (2009). Too young for respect? Realising respect for young children in their everyday environments. A cross-cultural analysis. (Working Paper No. 54). The Hague, The Netherlands: Bernard van Leer Foundation.

Ginsburg, H. P. (1989). Children's arithmetic: How they learn it and how they teach it. Texas: Pro Ed.

Ginsburg, K. R. (2007). The importance of play in promoting healthy child development and maintaining strong parent-child bonds. American Academy of Pediatrics, 119(1), 182-191.

Glasser, W. (1998). Choice theory. New York: Harper Collins.

Gleave, J., \& Cole-Hamilton, I. (2012). A world without play: A literature review. Retrieved from http://www.playengland.org.uk/media/371031/a-world-without-play-literatu...

Hirsh-Pasek, K., \& Golinkoff, R. M., with Eyer, D. (2003). Einstein never used flash cards: How our children really learn and why they need to play more and memorize less. Emmaus, PA: Rodale Press.

Hohmann, M., Weikart, D. P., \& Epstein, A. S. (1995). Educating young children: Active learning practices for preschool and child care programs. Ypsilanti, MI: HighScope Press.

Hoitenga, D. J. (1991). Faith and reason from Plato to Plantinga: An introduction to reformed epistemology. Grand Rapids, MI: State University of New York Press. 
Jacobson, L. (2008). Children’s lack of playtime seen as troubling health, school issue. Education Week, 28(14), 1-15.

Jarvis, P. (2007). Monsters, magic and Mr. Psycho: A biocultural approach to rough and tumble play in the early years of primary school. Early Years, 27(2), 171-188.

Leichtman, M. (1996). The Rorschach: A developmental perspective. New Jersey: The Analytic Press.

Lewis, P., Boucher, J., Lupton, L., \&. Watson S. (2000). Relationships between symbolic play, functional play, verbal and non-verbal ability in young children. International Journal of Language Communication Disorder, 35(1), 117-27.

Little, S. G., \& Akin-Little, A. (2008). Psychology’s contributions to classroom management. Psychology in Schools, 45(3), 227-234.

Mahoney, J. L., Harris, A. L, \& Eccles, J. S. (2008). The over-scheduling myth. Child Trends: Research to results brief. Retrieved from www.childtrends.org/Files//Child_Trends2008_02_27_Myth.pdf

Matthews, J. (2008, December 26). Is recess necessary? The Washington Post. Retrieved from http://www.washingtonpost.com/wp-dyn/content/article/2008/12/26/AR200812...

Merleau-Ponty, M. (1968). The visible and the invisible. Evanston: Northwestern University Press.

Murray, B. (2008). Running from Ritalin. Retrieved from http://www.upliftprogram.com/article_adhadd.html

Noddings, N. (1992). The challenge to care in schools. New York: Teachers College Press.

Paley, V. G. (2005). A child's work: The importance of fantasy play. Chicago: University of Chicago Press.

Pellegrini, A. D., \& Smith, P. K. (1993). School recess: Implications for education and development. Review of Educational Research, 63(1), 51-67.

Pepler, D. J., \& Ross, H. S. (1981). The effects of play on convergent and divergent problem solving. Child Development, 52(4), 1202-1210.

Peterson, M. L. (1986). Philosophy of education: Issues and options. Illinois: InterVarsity Press. Piaget, J. (1970). The science of education and the psychology of the child. New York: Orion Press.

Pomerantz, A., \& Bell, N. (2007). Learning to play, playing to learn: FL learners as multicompetent language users. Applied Linguistics, 28(4), 556-578. 
Ricoeur, P. (1981). The hermeneutical function of distanciation. In J. B. Thompson (Ed., Trans.), Hermeneutics and the social sciences (pp.131-44). Cambridge: Cambridge University Press.

Rogers, C. R. (1951). Client-centered counselling. Boston: Houghton-Mifflin.

Rodgers, J. (2009, March 5). Schools already making play pay. Greeley Tribune.

Scott, E., \& Panksepp, J. (2003). Rough-and-tumble play in human children. Aggressive Behaviour, 29, 539-551.

Smilansky, S. (1968). The effects of socio-dramatic play on disadvantaged children. New York: John Wiley and Sons.

Smilansky, S. (1990). Sociodramatic play: Its relevance to behavior and achievement in school. In E. Klugman \& S. Smilansky (Eds.), Children’s play and learning, (p. 19). New York: Teacher’s College.

Sokolowski, R. (2000). Introduction to phenomenology. New York: Cambridge University Press.

Steiner, C. (1997). Achieving emotional literacy. London: Bloomsbury Publishing.

Sutton-Smith, B. (1997). The ambiguity of play. Cambridge, MA: Harvard University Press.

Symes, C., \& Preston, N. (1997). Schools and classrooms. Sydney: Longman.

Van Manen, M. (1997). Researching lived experience: Human science for an action sensitive pedagogy. London, Ontario: Althouse Press.

Van Manen, M., \& Levering, B. (1996). Childhood secrets. New York: Teachers College Press.

Vygotsky, L. S. (1978). Mind in society: The development of higher mental processes. Cambridge, MA: Harvard University Press.

Wells, L. C. (2003). Teaching peace: A guide for the classroom and everyday life. Retrieved from www.wagingpeace.org/menu/programs/youth-outreach/peace-ed-book/teaching-...

Wenner, M. (2009, January 28). The serious need for play. Scientific American Mind, 23-29.

Winnicott, D. W. (1971). Playing and reality. Suffolk: Tavistock Publication.

Wyver, S. R., \& Spence, S. H. (1999). Play and divergent problem solving: Evidence supporting a reciprocal relationship. Early Education and Development, 10(4), 419-444.

Yang, O. S. (2000). Guiding children’s verbal plan and evaluation during free play: An application of Vygotsky's genetic epistemology to the early childhood classroom. Early Childhood Education Journal, 28(1), 3-10. 
Zentall, S. S., \& Javorsky, J. (2007). Professional development for teachers of students with ADHD and characteristics of ADHD, Behavioral Disorders, 32, 78.

\section{Endnotes}

${ }^{1}$ Reformed epistemologists note that the warrant for interpreting personal experience as veridical is arrived at inductively as a properly basic belief vis-à-vis the conditions under which those beliefs are identified. For example, take the belief that I can see my painting of a forest hanging on the classroom wall (let's call this belief T). Now take two conditions: (A) I am in the classroom working on a set task designed by the teacher; (B) I am at home playing on the computer. $\mathrm{T}$ is properly basic at $\mathrm{A}$, but not properly basic at $\mathrm{B}$.

${ }^{2}$ The idealism that I refer to here is that of George Berkeley and G. W. F. Hegel, who both held to idealistic positions. The central metaphysical affirmation is that physical objects are either unreal in themselves or much less real than ideas.

${ }^{3}$ In addition, psychiatrist Dr. William Glasser, author of Choice Theory (1998), argues that play ( i.e., fun and freedom) are genetic requirements for mental health. Melinda Wenner reports in Scientific American Mind, January 28, 2009, that free, imaginative play is necessary for normal social, emotional, and cognitive development. 